경부혈관 초음파 표준검사지침. 1 부 - 기본 원리 및 표준검사 방법

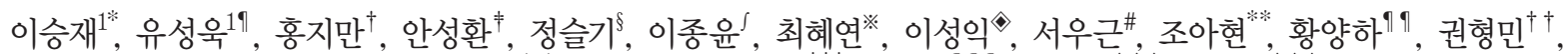

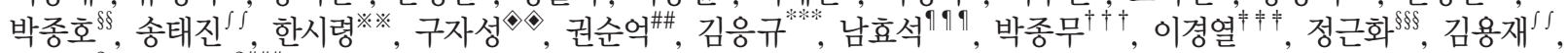
김상범 2 , 송희정 $2 \#$ \#\#

순천향대학교 의과대학 부천병원 신경과, 고려대학교 의과대학 안암병원 신경과", 아주대학교병원 신경과 ${ }^{\dagger}$, 조선대학교병원 신경과 ${ }^{\dagger}$, 정슬기신경과의원, 국립중앙의료원 신경과', 강동경희대학교병원 신경과*, 원광대학교 의과대학 산본병원 신경과 , 성균관대학교 삼성서울병원 신경과\#, 가톨릭대학교 여의도성모병원 신경과** 경북대학교병원 신경과 ${ }^{11}$, 서울대학교 보라매병원 신경과 ${ }^{\dagger}$, 한양대학교 명지병원 신경과\$ , 이화여자대학교 의과대학 신경과 가톨릭대학교 성빈센트병원 신경과**, 가톨릭대학교 서울성모병원 신경과 , 울산대학교 의과대학 서울아산병원 신경과\#, 인제대학교 부산백병원 신경과*** 연세대학교 의과대학 세브란스병원 신경과 ${ }^{191}$, 을지대학교 의과대학 을지병원 신경과 ${ }^{\dagger \dagger}$, 연세대학교 의과대학 강남세브란스병원 신경과 ${ }^{\ddagger}{ }^{\ddagger}$, 서울대학교병원 신경과 $\$ \$$, 충남대학교병원 신경과 \#\#

\title{
Extracranial Carotid Duplex Ultrasonography. Part I - Basic Principles and Standard Examination for Carotid and Vertebral Arteries, and Jugular Veins
}

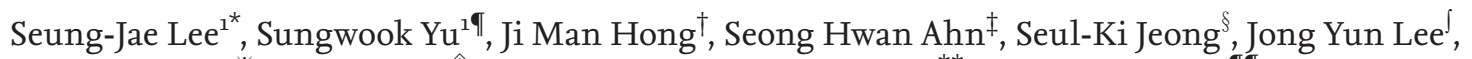
Hye-Yeon Choi*, Sung Ik Lee ${ }^{\star}$, Woo-Keun Seo\#, A-Hyun Cho ${ }^{* \star}$, Yang-Ha Hwang ${ }^{\top \uparrow}$, Hyung-Min Kwon ${ }^{\dagger \dagger}$, Jong-Ho Park ${ }^{\S \S}$, Tae-Jin Song ${ }^{\iint}$, Si-Ryung Han ${ }^{* *}$, Jaseong Koo ${ }^{\star}$, Sun U Kwon ${ }^{\# \#, ~ E u n g-G y u ~ K i m ~}{ }^{\star \star *}$,

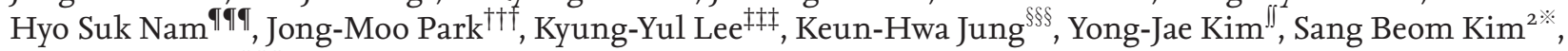
Hee-Jung Song 2 \#\#\#

Departments of Neurology, Soonchunhyang University College of Medicine*, Korea University College of Medicine", Ajou University College of Medicine ${ }^{\dagger}$, Chosun University College of Medicine ${ }^{\ddagger}$, JSK Neurology Clinic ${ }^{\S}$, National Medical Center, Kyung Hee University Hospital at Gangdong *, Wonkwang University College of Medicine ${ }^{\star}$, SungKyunKwan University Samsung Medical Center\#, The Catholic University of

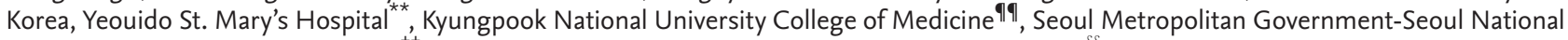
University Boramae Medical Center ${ }^{\dagger \dagger}$, Myongji Hospital, Hanyang University College of Medicine ${ }^{\S \S}$, Ewha Womans University College of Medicine $\iint$, The Catholic University of Korea St. Vincent's Hospital ${ }^{* *}$, The Catholic University of Korea Seoul St. Mary's Hospital ${ }^{\diamond}$, Asan Medical Center, University of Ulsan College of Medicine"\#, Inje University College of Medicine ${ }^{\star \star \star}$, Yonsei University College of Medicine

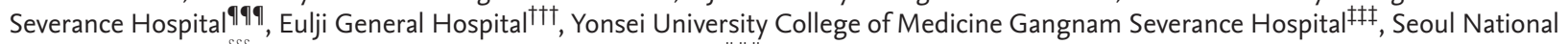
University Hospital ${ }^{\S \S \S}$, Chungnam National University Hospital\#\#\#, Korea

Use of ultrasound is safe in humans, and has been widely used in medical applications. B-mode sonography produces cross-sectional images and Doppler sonography measures blood flow velocities. Carotid duplex ultrasonography (CDU) has been mainly utilized in cerebrovascular disease. Recently, its use has been expanded in Parkinson's disease and neuromuscular disease as well as pain management. Point-of-care ultrasound is used in emergency and intensive care settings, and has the advantage of short examination time, relatively low cost, and reproducibility. However, the results may vary depending on the examiner's skill. Therefore, a standard protocol for examination is needed. This practice guideline discusses basic principles, artifacts, and standard techniques, and thus can improve understanding of CDU for neck vessels.

J Neurosonol Neuroimag 201\$;10(2):47-60

Key Words: Carotid duplex ultrasonography; Vertebral artery; Jugular vein; Basic principles of ultrasound; Guideline; Standard examination

${ }^{1}$ Seung-Jae Lee and Sungwook Yu contributed equally to this work as first author.

${ }^{2}$ Sang Beom Kim and Hee-Jung Song contributed equally to this work as corresponding authors.
Received: September 21, 2018 Revised: October 26, 2018 Accepted: November 20, 2018

Address for correspondence: Sang Beom Kim

Department of Neurology, Kyung Hee University Hospital at Gangdong, 892 Dongnamro, Gangdong-gu, Seoul 05278 Korea

E-mail: sbkim@khu.ac.kr

Hee-Jung Song

Department of Neurology, Chungnam National University Hospital, 282 Munhwa-ro, Jung-gu, Daejeon 35015 Korea E-mail:nrsono@cnuh.co.kr 
서 론

초음파는 인체에 비침습적이고 안전하며 $\mathrm{B}$ 방식을 이용한 단면영상뿐만 아니라 도플러를 이용한 혈류검사가 가능하므 로 다양한 질환에서 사용되고 있다. 신경과 영역에서는 뇌혈 관질환에서 널리 사용되어 왔는데 최근 파킨슨병을 비롯한 퇴 행성 질환, 말초신경 및 근육질환, ${ }^{2}$ 통증치료 ${ }^{3}$ 등에서 활용되 고 특히 응급실 및 중환자실에서 신속한 진단 및 처치에 적용 (point-of-care ultrasound) ${ }^{4}$ 되면서 그 활용영역을 넓혀가 고 있다. 초음파검사는 비교적 빠른 시간에 검사가 가능하고 적은 비용으로 반복적으로 할 수 있는 장점이 있다. 반면에 숙 련된 검사자가 아니면 검사 및 해석에 어려움을 겪을 수 있어 비숙련자가 쉽게 접근하기 어려운 단점이 있다. 따라서 검사기 관 및 검사자 간의 격차를 해소하기 위해서는 표준검사법이 필 요하다. 최근 대한신경초음파학회에서 경두개도플러 초음파검 사법에 대한 가이드라인 5 을 출판하였고 그 연장선상에서 경 부혈관에 대한 초음파검사 표준검사지침을 제시하고자 한다. 표준검사지침 1 부에서는 초음파검사의 기본원리에 대한 설명 과 경동맥, 척추동맥 및 경정맥의 초음파 표준검사법을 제시하 여 검사의 원리 및 기초 테크닉을 익힐 수 있도록 하였고 이어 지는 2 부에서는 각각의 질환에 대한 내용을 기술하여 경부혈 관 초음파검사에 대한 내용을 총괄적으로 이해할 수 있도록 하 고자 한다.

\section{두개외 경동맥과 척추동맥의 정상 해부학(NOR- MAL ANATOMY OF EXTRACRANIAL CA- ROTID AND VERTEBRAL ARTERIES)}

\section{1. 경동맥(carotid artery)}

\section{우측에서는 대동맥궁(aortic arch)으로부터 팔머리동맥}

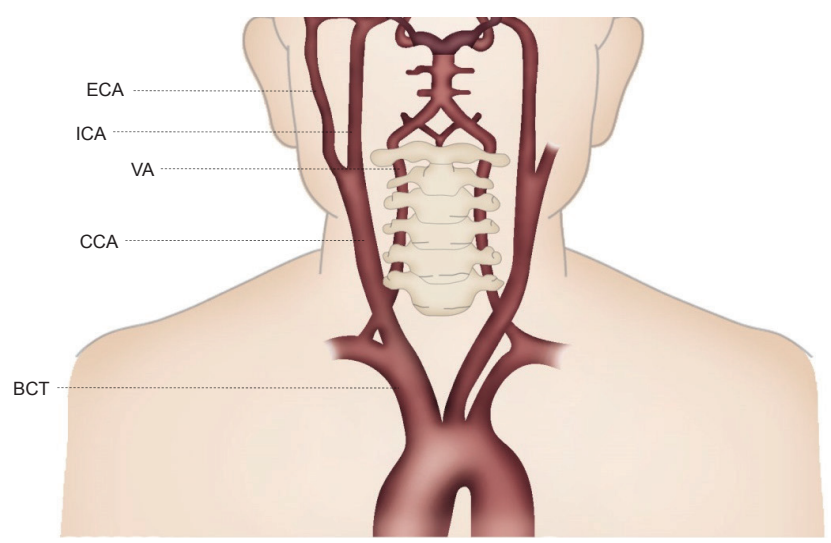

FIG. 1. Arterial branches to the brain. ECA; external carotid artery, ICA; internal carotid artery, VA; vertebral artery, CCA; common carotid artery, BCT; brachiocephalic trunk. (brachiocephalic, innominate artery)이 나온 후 쇄골하동 맥(subclavian artery)과 총경동맥(common carotid artery) 으로 나뉜다. 좌측에서는 대개 총경동맥과 쇄골하동맥이 직접 대동맥궁에서 나온다(Fig. 1).

총경동맥은 경정맥(jugular vein)과 평행하게 주행하다가 내경동맥과 외경동맥(internal \& external carotid arteries) 으로 나뉜다. 총경동맥의 분기 위치는 제 4 경추(C4) 부위가 약 $30 \%$ 정도이고 나머지 경우는 C2-3부터 C5까지 위아래로 분 포하고 있으며 여성에서 고위 경부에 위치하는 경우가 다소 많 은 편이다(Fig. 2). 분기위치가 높은 경우 경동맥내막절제술을 시행할 때 접근이 어려워 스텐트 적응증이 되기도 한다. 총경 동맥은 원위부에서 확장되어 경동맥팽대(carotid bulb)를 이 루고 내경동맥으로 이어진다. 내경동맥은 안구와 뇌에 혈류를 공급하는 혈관으로 두개강 안으로 들어가 뇌의 전순환(anterior circulation)을 이룬다. ${ }^{7}$

\section{2. 척추동맥(vertebral artery)}

척추동맥은 대개 쇄골하동맥(subclavian artery)에서 나오 지만 왼쪽 척추동맥의 4-6\%는 대동맥궁에서 직접 나오기도 한다. 오른쪽에 비하여 왼쪽 기시부는 깊고 낮아 초음파로 보 기가 다소 어렵다. 척추동맥 기시부 바로 바깥쪽에서 갑상목동 맥(thyrocervical trunk)이 쇄골하동맥에서 기시하여 혼동을 일으킬 수 있다. 척추동맥은 V1 (pre-transverse segment; 척추전구역: 기시부부터 C6 가로구멍 입구 사이), V2 (vertebral segment; 척추구역: C6-C2 가로구멍을 통과하는 부위), V3 (atlantic segment; 고리뼈구역: C2 척추와 고리뼈 사이 의 구불구불한 부분), V4 (intracranial segment; 두개내 구 역) 등 네 부분으로 나뉜다(Fig. 3). 양측 척추동맥은 그 굵기 가 $50 \%$ 이상에서 서로 다르다. ${ }^{8}$

\section{경동맥이중초음파의 원리(PRINCIPLES OF CAROTID DUPLEX ULTRASONOGRAPHY)}

1. Brightness (B) 방식(B-mode)

경동맥이중초음파는 하나의 압전체에서 초음파를 송신하고 수신하는 간헐파(pulsed wave)를 사용한다. 탐색자(trans-

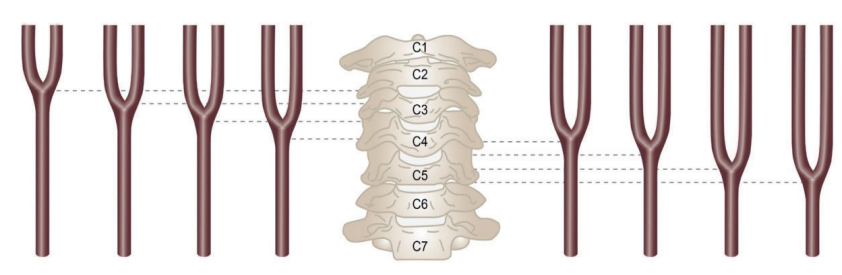

FIG. 2. Anatomical locations where common carotid artery branches. 
ducer)는 초음파를 방출하고, 소리저항(acoustic impedance) 이 서로 다른 조직들의 경계면에서 반사되어 돌아오는 에코를 받는다(pulse-echo principle). 에코가 돌아오는 시간을 측 정하면 반사체(reflector)의 위치를 알 수 있고 이것을 회색조 (gray scale)의 해부학적 2차원 영상으로 구현한 것이 B방식 으로 혈관벽이나 혈관내강에 대한 형태학적 정보를 제공한다. 소리저항의 차이가 클수록 돌아오는 에코의 강도가 증가하고 $\mathrm{B}$ 방식 영상에서 밝은 에코(hyperechoic)를 나타낸다. ${ }^{9}$ 해상도 를 높이기 위해 적어도 $7 \mathrm{MHz}$ 주파수 이상의 탐색자를 사용 하도록 권고되지만 피검자의 신체적 조건에 맞게 주파수를 조 정한다. 혈관의 종단면과 횡단면을 따라 해부학적 구조를 살펴 보는 목적으로 사용한다. ${ }^{10}$

\section{2. 도플러(Doppler)}

4-12 MHz의 높은 주파수의 초음파를 이용하여, 혈관내 혈 류의 속도 및 도플러 스펙트럼파형(Doppler spectral waveform)을 측정할 수 있다. 도플러검사법에는 연속파형(continuous wave, CW)과 간헐파형(pulsed wave, PW)이 있는 데 이들은 서로 보완적이다. 탐색자는 전기에너지를 파동에너 지, 즉 초음파로 바꾸고 인체조직으로부터 반사된 파동에너 지를 다시 전기에너지로 바꾸어 수신기에 전달하는 압전결정 (piezoelectric crystal)을 가지고 있다.

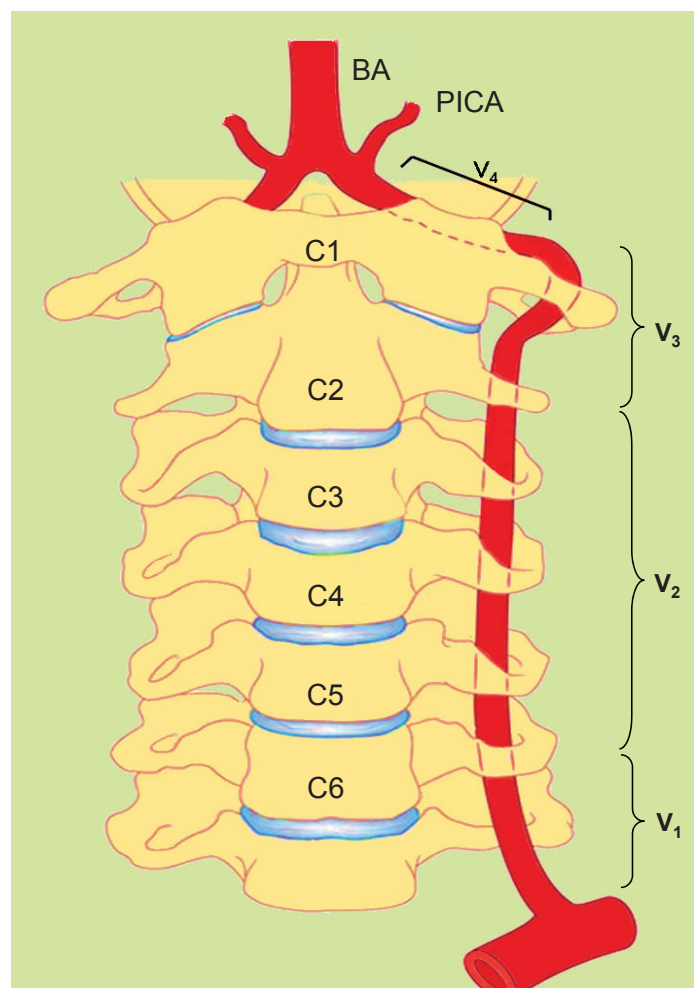

FIG. 3. Segments of vertebral artery. BA; basilar artery, PICA; posterior inferior cerebellar artery.
간헐파형 도플러에서는 하나의 압전결정이 초음파를 보내 는 역할과 반사체로부터 돌아오는 에코를 수신하는 역할 모두 를 수행한다. 이때, 초음파가 되돌아오는 시간을 측정할 수 있 으므로 반사체의 깊이를 알 수 있다. 혈류속도는 입사 초음파 와 되돌아온 에코 사이의 주파수 변위(frequency shift)에 비 례하며, 입사각을 포함한 도플러 방정식을 이용하여 산출할 수 있다. 혈류와 초음파 빔의 방향이 이루는 각도는 코사인 (cosine)값으로 보정한다. 이 각도가 $0^{\circ}$ 일 때는 각도 보정이 필 요 없고, $90^{\circ}$ 일 때는 코사인값이 0 이 되어 주파수 변위가 일어 나지 않으므로 움직임이 측정되지 않으며, $60^{\circ}$ 를 넘어서면 코 사인 각도로 보정하더라도 혈류속도의 왜곡이 발생한다. 간헐 파형도플러의 또 다른 특징은 하나의 압전결정이 초음파를 보 내고 받으므로 송-수신 사이에 발생하는 샘플링 속도인 펄스 반복주파수(pulse repetition frequency, $\mathrm{PRF}$ )가 있다는 것 이다. 혈류속도가 지나치게 높아 이를 측정할 때 발생하는 주 파수 변위가 펄스반복주파수의 $1 / 2$ (Nyquist limit)을 초과하 게 되는 경우에는 속도 측정 한계를 넘어 둘러겹침(aliasing) 이 나타나게 된다. ${ }^{11}$

간헐파형 도플러와 달리, 연속파형 도플러는 두 개의 분리된 압전결정이 초음파를 연속적으로 각각 보내고 받으므로, 반사 체로부터 특정 초음파가 돌아오는 시간을 알 수 없다. 따라서 깊이 등 반사체의 위치에 대한 정보를 알 수 없고, 이런 이유 로 초음파 투과 각도를 교정하여 혈류속도를 구할 수 없다. 하 지만 펄스반복주파수가 없으므로(연속적인 샘플링 가능) 높은 혈류 속도를 둘러겹침 없이 측정할 수 있다.

\section{3. 색혈류지도화(color flow mapping)}

$\mathrm{B}$ 방식 흑백영상에 도플러 주파수 변위, 즉 혈류속도의 정보 를 혈관 내에 색(빨강과 파랑)으로 나타낼 수 있다(Fig. 4). 색 혈류지도화는 탐색자에 상대적인 혈류방향을 명확하게 두 가 지 색깔로 서로 다르게 표현하는 것이다. 하지만 초음파 빔과

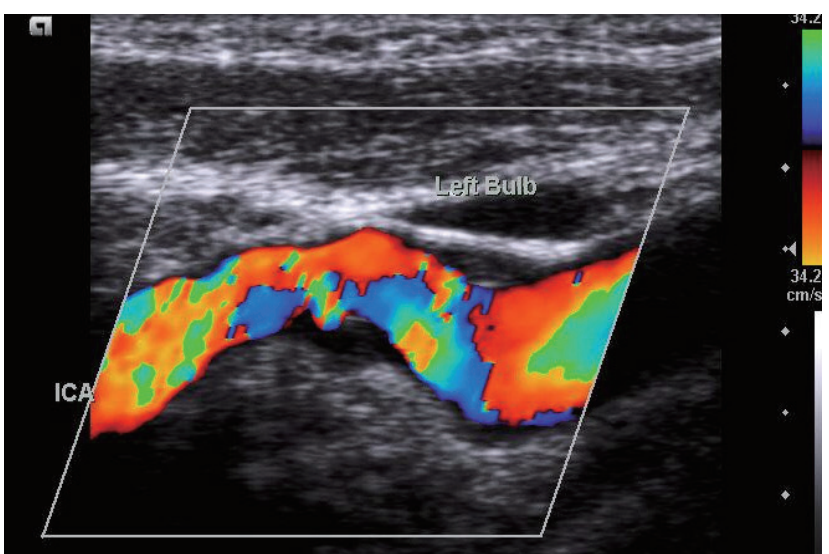

Fig. 4. Color flow mapping. 
혈류 사이 각도가 $90^{\circ}$ 가 되면 어떠한 주파수 변위도 일어나지 않게 되고, 따라서 이러한 혈류 흐름은 색상으로 표현되지 않 는다. 색증폭(color gain)을 지나치게 높이면 혈류 흐름을 나 타내는 색상이 혈관 밖까지 나타나므로 이에 주의한다. 이 방 법은 도플러 속도 측정 원리를 이용하므로 경우에 따라 둘러겹 침이 나타날 수 있다. ${ }^{12}$

\section{4. 파워도플러(power Doppler)}

도플러 원리를 이용하지 않고, 혈관 내 흐르는 적혈구로부터 반사되는 초음파 에너지의 변화를 분석하여 방향과 상관없는 혈류 흐름을 한가지 색으로 나타낸다(Fig. 5). 따라서 혈류속 도나 방향을 알 수 없다. 하지만, 도플러효과를 이용하는 색혈 류지도화와 달리 신호-잡음비(signal-to-noise ratio)가 높 아 폐색혈관 확인에도 유용하고, 깊은 위치에 있는 혈관의 혈 류 흐름을 알 수 있다. 또한 각도에 독립적(angle-independent)이어서 구불구불한 혈관을 시각화할 수 있다. ${ }^{12,13}$

\section{두개외 경동맥과 척추동맥의 표준검사 방법}

1. 총경동맥, 내경동맥, 외경동맥, 척추동맥 탐색 및 각 혈관 구별법

검사자가 이용할 수 있는 경동맥 초음파검사의 자세에는 두 가지가 있는데, 환자 머리 위에서 검사하는 방법과 환자 옆 좌-우측에 앉아서 하는 방법이 있다. 머리 위에서 검사하는 경우에는 양손을 이용하면서 환자에게 많은 자세를 요구할 수 있으나 양손이 익숙한 검사자에게 가능하고 더 많은 공간이 요 구된다. 이러한 이유 때문에 실제 환자 옆에서 검사하는 경우 가 훨씬 더 많다. 검사시 베개를 사용할 사용할 수 있으며, 환 자의 턱을 가볍게 올리고 바로 누워서 시행한다. 얼굴을 검사

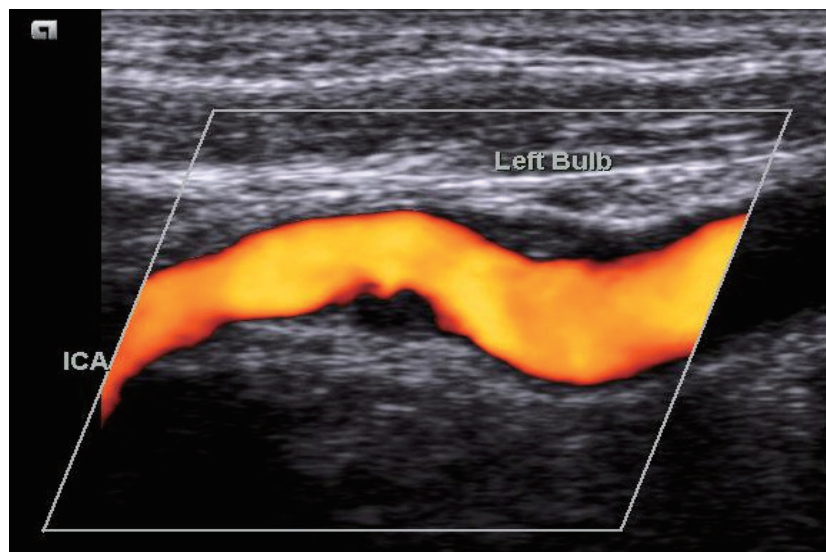

Fig. 5. Power Doppler.
부위 반대편으로 돌리면 넓은 시야를 얻을 수 있지만 너무 기 울이면 해부학적 구조가 뒤틀리거나 혈관들, 특히 정맥이 쉽게 눌릴 수 있다. ${ }^{14}$

검사는 우선 경동맥을 횡단면입사(cross-sectional insonation)하여 혈관의 근위부에서 머리 쪽 방향으로, 또는 머리 쪽에서 아래방향으로 관찰한다. 다음으로 종단면입사(longitudinal insonation)하여 경동맥 혈관의 전체 모양을 파악한 다(Fig. 6).

총경동맥은 머리 방향으로 올라가면서 내경동맥과 외경동맥 으로 나뉘게 되는데 이들을 구별하는 것이 매우 중요하다. 내 경동맥은 외경동맥에 비하여 보통 직경이 더 크다. 내경동맥이 일반적으로 더 깊은 곳에 있고 유돌기(mastoid process)쪽을 향한다. 이에 반하여 외경동맥은 표면에 위치하고 안면을 향한 다. 내경동맥은 가지혈관이 없고 외경동맥은 있다. 내경동맥은 수축기혈류속도가 느리고 확장기말혈류속도가 빠른 낮은 저항 파형(low-resistance waveform)이고 외경동맥은 이와 반대 모양의 높은 저항파형(high-resistance waveform)을 보인다 (Fig. 7), 측두부 얕은관자동맥(superficial temporal artery) 을 두드리면 내경동맥은 파형이 동요하지 않지만 외경동맥은
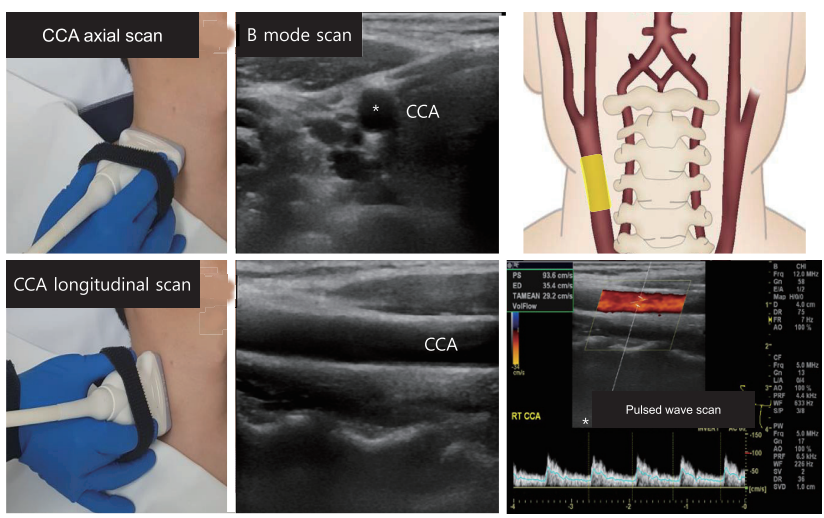

FIG. 6. Examination of common carotid artery (CCA).
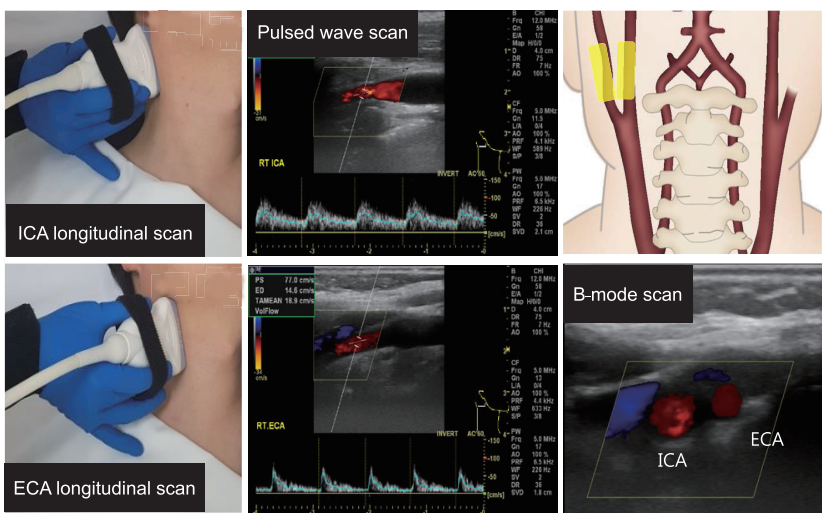

FIG. 7. Examination of internal and external carotid arteries. ECA; external carotid artery, ICA; internal carotid artery. 
파형이 영향을 받아 튀게 된다.

척추동맥은 쇄골하동맥에서 나오는 기시부와 척추구역(V2) 을 검사할 수 있다. 척추구역에서는 가로돌기로 인하여 음향 음영(acoustic shadow)이 발생하여 초음파입사가 되지 않아 그 사이에 있는 척추동맥 부위만을 관찰할 수 있으며, 이를 이 용하여 척추동맥임을 알 수 있다. ${ }^{15,16}$ 척추동맥을 관찰하려 할 때 총경동맥을 종단면입사하여 관찰하고 탐색자를 목의 후외 측으로 옮긴 후 가로돌기의 음향음영을 찾아 음영과 음영 사이 의 V2 척추 동맥구역을 관찰한다. 척추동맥의 기시부는 어깨 를 아래로 내릴 때 가장 잘 관찰된다. 총경동맥이나 갑상목동 맥 등 다른 동맥과 구별이 어려울 때는 외-내경동맥을 확인할 때와 같은 방법으로 $\mathrm{C} 1$ 고리뼈부위의 타진에 의하여 파형이 영 향을 받아 튀는지 확인하여 척추동맥인지 감별한다(Fig. 8).

\section{2. 검사 방법}

초음파검사는 $7 \mathrm{MHz}$ 이상, 선형탐색자(linear array transducer)를 사용하며, 깊이는 3-4 cm, frame rate는 25 $\mathrm{Hz}$ 이상으로 조절한다. 내경동맥과 외경동맥의 도플러검사는 분기로부터 각 혈관의 근위부 $1 \mathrm{~cm}$ 부위에서 시행한다. 혈류 주행방향과 초음파 주사 방향의 각도가 $60^{\circ}$ 이내가 되도록 하 고 표본용적(sample volume) 커서를 혈관중앙에 평행하게 놓 아 정확한 혈류속도를 측정하도록 한다. 일반적으로 많이 사용 되는 표본용적은 직경 $2 \mathrm{~mm}$ 이다. 협착이 관찰된다면 협착부 위 및 협착 전후 위치에서 혈류속도를 측정하여 협착의 정도를 평가한다. 횡단면스캔에서 죽상판(plaque)이 관찰되었다면 탐 색자를 $90^{\circ}$ 돌려 종단면스캔으로 죽상판을 관찰한다. 종단면 검사시 혈관의 가까운 벽(near wall)과 먼 벽(far wall) 모두 관찰하며, 앞쪽(anterior), 옆쪽(lateral), 뒤쪽(posterior)의
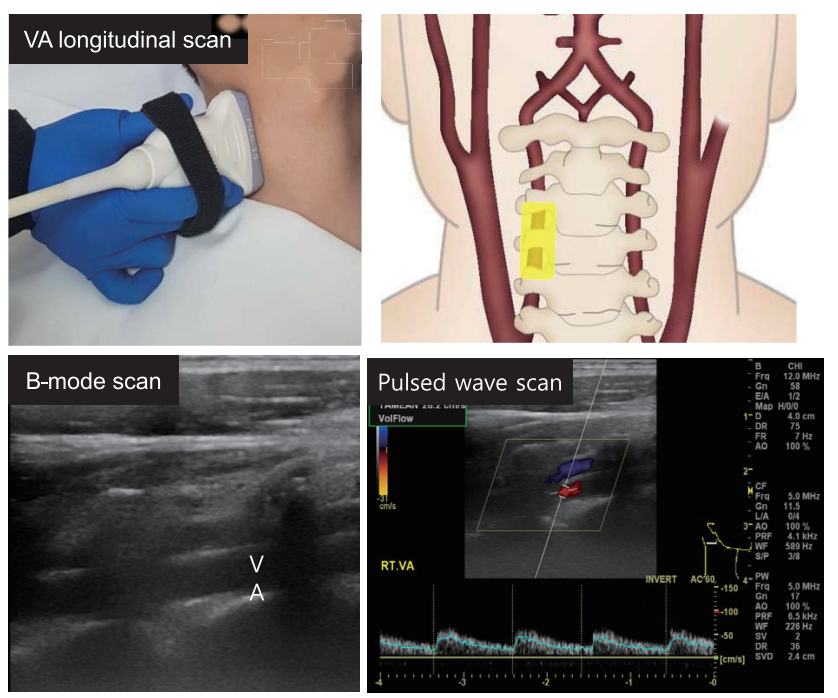

FIG. 8. Examination of vertebral artery (VA).
세 각도에서 관찰하여 내강으로의 돌출 정도, 형태, 크기, 위 치를 평가한다(Fig. 9). 각 혈관 분절마다 적어도 세 각도에서 $3-5$ 회의 박동 동안 영화고리(cine-loop)를 관찰하도록 한다. 이때 표면의 울퉁불퉁함이나, 저에코지역, 궤양형성 등 불안정 성 죽상판의 양상을 주의 깊게 살펴보아야 한다. 도플러검사는 해부학적인 방향성을 확인하며 뚜렷한 협착이 있는 경우 혈류 속도를 측정하여 협착의 정도를 확인하는 역할을 한다. ${ }^{17}$

\section{허상(ARTIFACTS)}

초음파 영상에서 빔은 조직을 통과할 때 직선을 따르고, 조 직에서 빔의 속도는 일정하다고 가정한다. 이러한 가정을 벗 어나는 경우, 목표물이 잘못된 위치에서 보일 수 있다. 허상은 영상의 질에는 영향을 주지만, 이것을 인지하는 것은 대개 어 렵지 않다. 기계적인 설정이 잘못되어 영상에 문제가 발생하는 것은 허상이라고 하지 않으므로 여기에서는 언급하지 않는다.

허상을 만드는 것은 굴절(refraction), 반사(reflection), 회 절(diffraction), 간섭(interference), 편향(deflection)과 같 은 음파의 물리적인 특성에서 기인한다. 신경초음파검사에서 흔히 관찰할 수 있는 허상은 다음과 같다.

\section{1. 반향(reverberation)}

탐색자의 접촉면과 평행한 위치에 반사될 만한 조직이 있는 경우, 초음파빔이 이들 조직 사이를 왔다 갔다 하는 내부적 반 사(internal reflection)가 발생할 수 있는데 이때 초음파는 늦 게 돌아오는 에코들을 더 깊은 조직으로부터 돌아오는 에코 로 해석한 영상을 보여준다. 따라서 동일 간격의 평행한 선들 이 실상보다 깊은 위치에 반복적으로 나타난다(Fig. 10). 내중 막두께(intima-media thickness, IMT)를 먼 벽에서 측정하

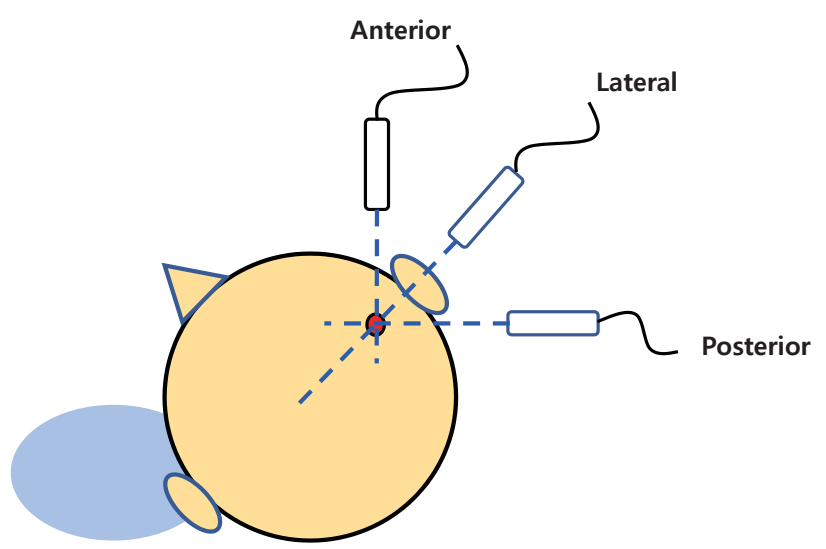

FIG. 9. Head position and probe orientation for carotid ultrasound scanning. ${ }^{10}$ 
는 이유는 가까운 벽은 반향허상으로 정확한 측정이 어렵기 때 문이다(Fig. 11). 초음파 입사각(insonation angle)을 적절하 게 조절하면 반향허상은 쉽게 사라진다. 대표적인 반향허상으 로 혜성꼬리허상(comet-tail artifact, Fig. 12)과 여운허상 (ring-down artifact)이 있다.

참고로 혜성꼬리허상이란 두 접촉면 사이가 너무 가까울 경 우에 매우 짧은 간격으로 많은 내부적인 반향들이 만들어지면 서 많은 에코들이 탐색자로 오면서 나타나게 되는 것을 말한다.

\section{2. 굴절(refraction)}

굴절은 파동이 진행을 하다가 다른 매질을 통과할 때 매질의 경계면에서 파동의 진행방향이 ㄲㄲㄲ이는 현상을 말한다. 즉 2 개 의 다른 조직이 만나는 면에서 초음파의 속도가 달라지면서 빔 의 방향이 변화되는 현상을 말한다(Fig. 13).

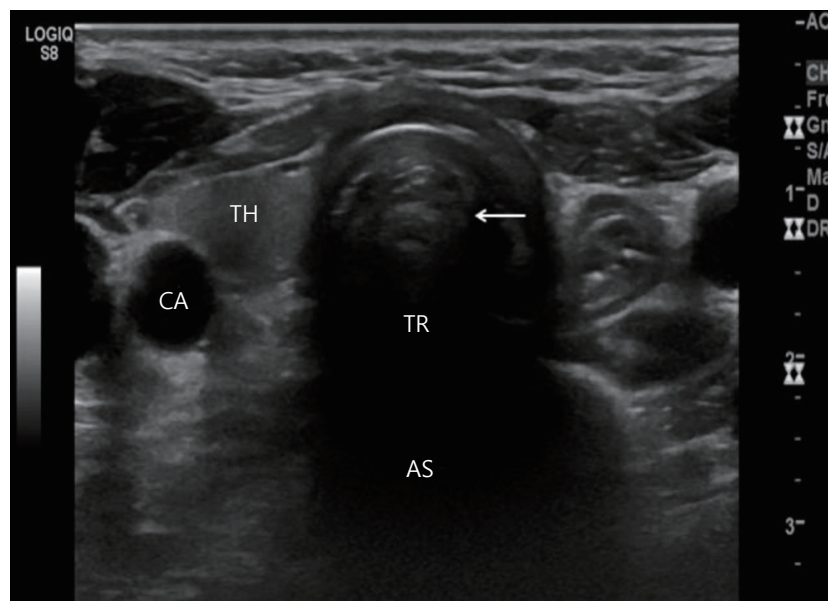

FIG. 10. Reverberation (arrow) and acoustic shadowing (AS) artifacts. $\mathrm{TH}$; thyroid gland, CA; carotid artery, TR; trachea.

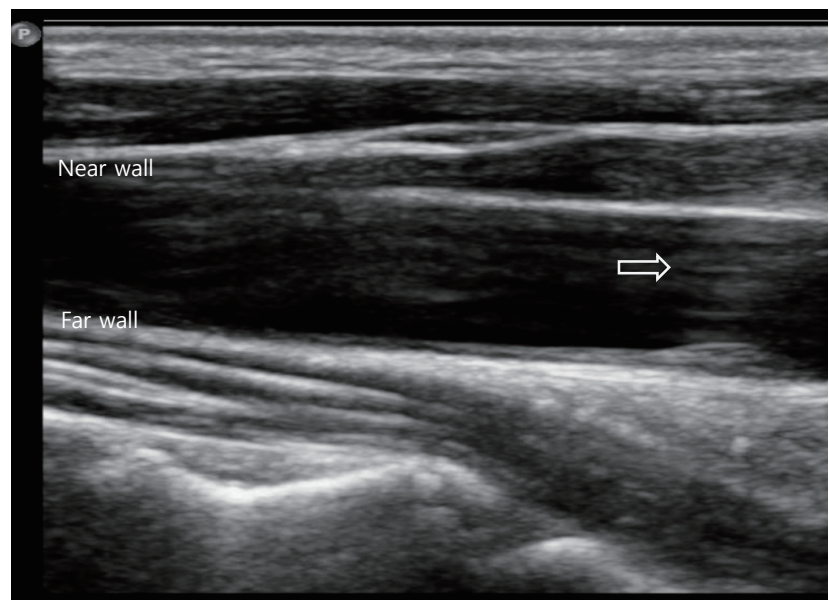

FIG. 11. Reverberation artifact of the near wall of the common carotid artery (open arrow).

\section{3. 그림자(shadowing)와 증강(enhancing)}

초음파는 조직 내에서 현저하게 감쇠되는데, 깊은 구조물로 부터 돌아오는 에코는 비슷한 얕은 구조물로부터 돌아오는 에 코에 비하여 언제나 훨씬 적다. 이를 극복하기 위해서 초음파 기계는 시간 이득 보상(time-gain compensation, TGC)이 라는 조절 도구를 이용하여, 깊은 구조물로부터 돌아오는 에코 를 증폭시킨다. 이를 위해서는 조직의 평균 감쇠율을 가정해야 하고, 각 깊이로부터 돌아오는 에코에 적용하여 적합한 이득을 계산할 수 있다. 이러한 감쇠가 과소평가되거나 과대평가되면 그림자(shadowing, Fig. 14)나 밝게 빛나는 형태(flaring or enhancement, Fig. 13)로 나타나게 된다.

\section{둘러겹침과 이를 교정하는 방법(ALIASING AND ITS OVERCOMING)}

\section{간헐파형 도플러 초음파에서는, 위에서 언급한 바, 매우 짧}
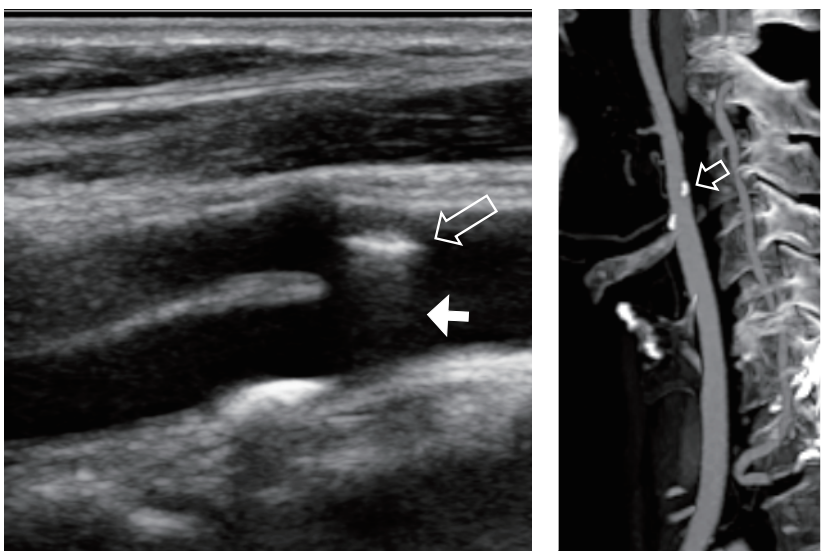

FIG. 12. Atherosclerotic plaque (open arrows) and comet-tail artifact (white arrow).
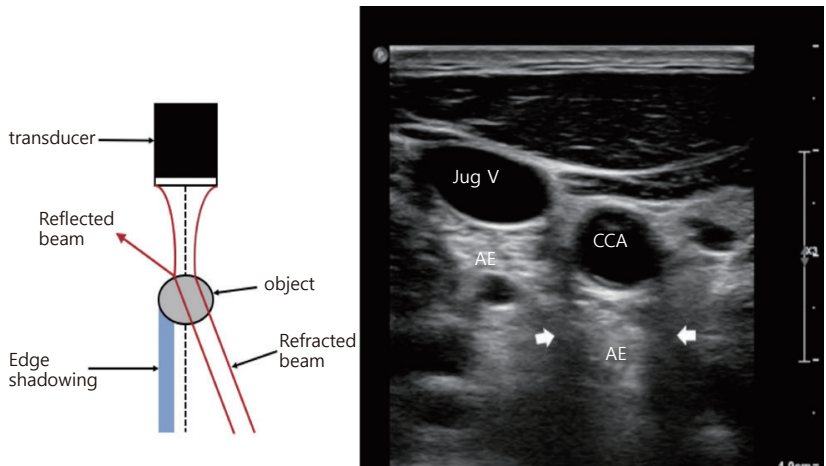

FIG. 13. Edge shadowing (white arrows) caused by refraction and reflection. AE; acoustic enhancement, CCA; common carotid artery, Jug $\vee$; jugular vein. 
은 형태의 펄스 신호를 거듭 방출(펄스 반복 주파수)한 후, 초 음파탐색자로 돌아오는 모든 에코들을 기록하여 분석하게 된 다. 최대로 감지할 수 있는 도플러 주파수 변위는 펄스 반 복 주파수(특정 시간 동안 반복되는 시그널의 펄스 수, $\mathrm{PRF}$, sampling rate)의 절반과 같다. 다시 말하여, 도플러 신호가 적절하게 변환되려면, 그것이 수집되는(sampled) 비율이 최소 한 도플러 신호의 최대주파수 변위의 2 배 이상이 되어야 한다. 이러한 기준을 충족시키지 못하고, 빠르게 움직이는 물체를 실 제 속도로 재구성할 수 있을 정도로 초음파 에코를 충분하게 수집하지 못할 때 둘러겹침이 발생한다.

이와 같이, 도플러 주파수(Doppler frequency)를 측정하 는 범위가 펄스 반복 주파수에 의하여 제한되어 있어. 이 한계 를 넘어서는 높은 속도는 실제와 반대 방향의 낮은 속도(reversed flow)로 보인다(Figs. 15 and 16). 둘러겹침을 극복하 는 방법은 펄스반복주파수(샘플링 속도)를 늘려 최대 도플러 주파수 변위를 Nyquist limit(펄수반복주파수의 1/2) 이내에 들도록 하는 것이다. 초음파 기계에서 펄스반복주파수에 해당 하는 스케일(scale)을 늘리고, 바닥선(baseline)을 최대한 낮 추면 대부분의 둘러겹침을 극복할 수 있다(Fig. 15).

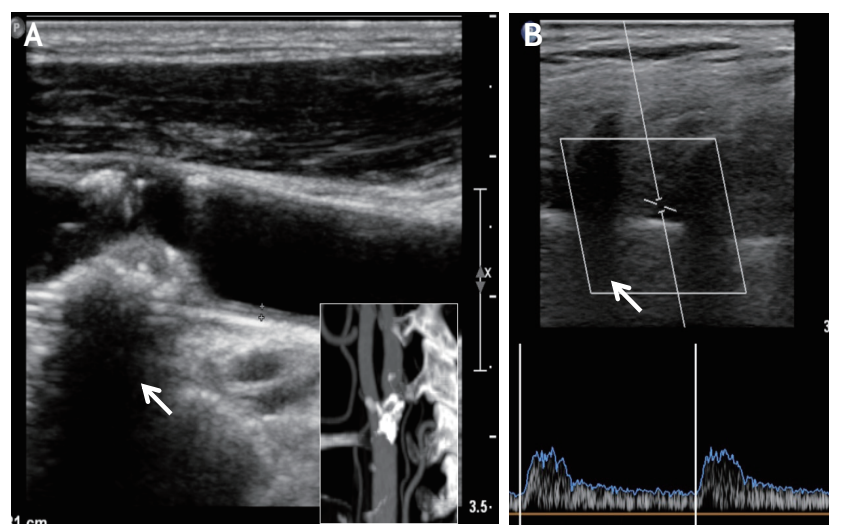

FIG. 14. Acoustic shadowing caused by atherosclerotic plaque (A, white arrow) and the transverse process of the vertebra ( $B$, white arrow)

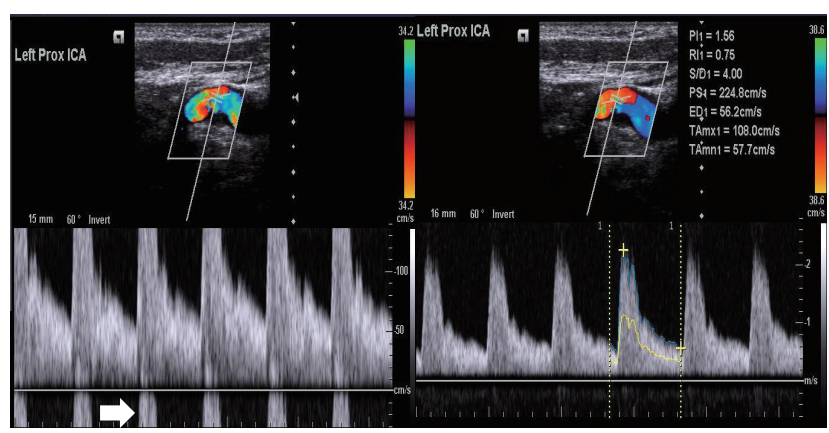

FIG. 15. Aliasing (left, white arrow) and its correction by scale modification (right).
도플러신호 샘플링은 도플러 파동 주기에 최소 두 번 이상 이루어져야 모든 속도 변화를 반영할 수 있다. Fig. 16은 도플 러 파동 한 주기 당 하나(2배 이하)의 샘플링을 한 예로 파동의 형태를 제대로 보여주지 못하고 있다.

\section{내중막두께}

혈관벽은 내막(intima), 중막(media), 외막(adventitia)의 세 층으로 구성되어 있다. 내중막두께는 초음파의 $\mathrm{B}$ 방식 종단 면 영상에서 평행한 이중선(double line)으로 관찰되며, 내강 에서부터 첫 번째 선은 내막을 나타내는 선이고 두 번째 밝은 선은 혈관 외막을 나타낸다. 중간의 검은 선은 중막(media), 즉 근육층을 나타내게 된다. 혈관내강과 내막 사이의 경계면에 서 중막과 외막 사이의 경계면까지의 두께를 내중막두께라고 한다(Fig. 17). 이러한 혈관벽 구조는 피부 쪽에 가까운 벽보 다는 깊은 쪽 먼 벽이 더 선명하게 관찰되기 때문에 일반적으 로 총경동맥이 분기되기 직전 부위 $10 \mathrm{~mm}$ 길이에서 먼 벽의 내중막두께를 측정하게 된다(Fig. 17). B방식 초음파를 이용한 내중막두께의 측정은 재현성이 매우 높아 동맥경화의 대리표 지자로 혈관 위험인자와는 독립적으로 심혈관위험을 예측하는 데 이용될 수 있다. 또한 내중막두께 측정은 주로 무증상 동맥 경화 환자를 평가하고 심뇌혈관위험을 예측하기 위하여 시행 되며 약물의 효과를 평가하거나 다양한 연구의 측정인자로 사 용되고 있다. ${ }^{10}$

\section{1. 측정방법}

이전의 연구에서는 다양한 방법으로 내중막두께를 측정하 여 각 결과의 상호비교와 임상적용이 어려운 경우가 많다. 이 러한 문제점을 극복하고 일정하고 재현 가능한 검사 결과를 얻 기 위해서는 표준화된 검사 방법에 따라 초음파검사를 시행하 는 것이 필수적이다. 여기서는 Mannheim carotid IMT and plaque consensus ${ }^{18}$ 와 American Society of Echocardiog-

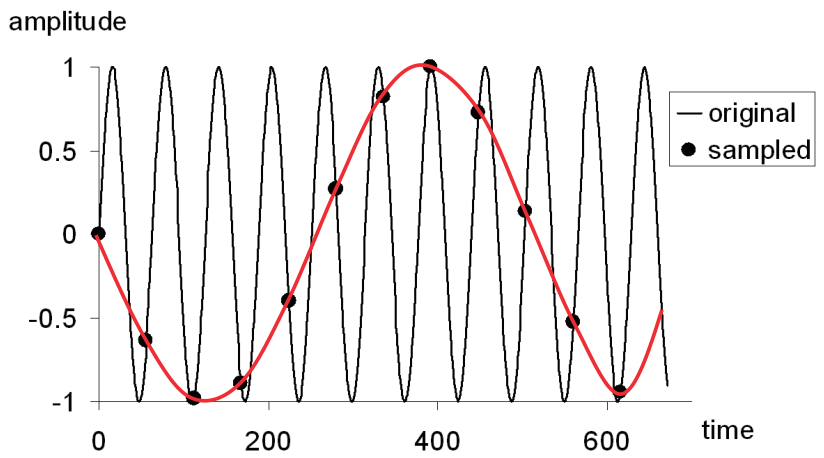

FIG. 16. Sampling frequency and aliasing. 
raphy ${ }^{10}$ 의 권고안을 참고하였다.

내중막두께는 가까운 벽과 먼 벽의 이중선이 평행하게 보이 는, 혈관이 종단면으로 스캔된 영상에서 측정한다. 내중막두께 는 내경동맥이나 경동맥팽대보다는 총경동맥에서 주로 측정하 는데, 총경동맥은 혈관이 크며 표면에 위치하고 움직임이 적어 쉽게 검사할 수 있어 재현성이 좋기 때문이다. 총경동맥 끝에 서 $5 \mathrm{~mm}$ 아래 원위부 먼 벽에서 $1 \mathrm{~cm}$ 길이의 곧은 동맥 부위 에서 내중막두께를 측정한다(Fig. 17).

$\mathrm{ECG}$ 를 같이 측정하는 경우 $3-5$ 회의 박동 동안 영화고리 (cine-loop)의 적절한 R파에서 얻은 정지 영상에서 내중막두 께를 측정한다. 세 각도의 스캔 중 가장 잘 보이는 스캔면에서 측정한다. 보통 옆(lateral)스캔에서 잘 관찰할 수 있다.

내중막두께의 측정은 경계선 추출법(edge detection systems)을 이용한 자동 또는 반자동 측정방법을 권고한다. ${ }^{2}$ 수 동측정방법으로도 유효한 결과를 얻을 수 있으나 자동측정방 법에 비하여 측정시간이 더 많이 걸리고 질 관리를 해야 하며 검사자 간 차이가 날 수 있다는 단점이 있다.

측정값으로 평균값, 최대값, 양측의 평균값이 이용되고 있 다. 평균값은 비정상값에 영향을 적게 받는 장점이 있다. 최대
값은 혈관질환의 상태를 더 잘 보여주는 지표값일 수 있으나 측정 또는 검사오류시 영향을 받을 수 있어 해석에 주의가 필 요하다.

\section{2. 내중막두께 참고치}

내중막두께 정상치는 연령, 성별, 인종에 따라 차이가 있으 며 검사 방법에 따라 다를 수 있다. 한국인의 내중막두께 정상 치에 대한 보고가 있기는 하나 심뇌혈관질환 위험 예측에 대한 대규모 연구가 필요한 실정이다. 남원시 지역사회 기반 코호 트 연구인 남원 연구(Namwon study)에서 45-74세의 2,595명의 건강한 사람을 대상으로 내중막두께를 측정하였다. ${ }^{19}$ 평균 총 경동맥 내중막두께는 연령 45-49, 50-54, 55-59, 60-64, 65-69, 70-74세에 따라 남성(713명)에서는 각각 0.614 , $0.671,0.711,0.759,0.783,0.787 \mathrm{~mm}$ 였으며 여성(1,882명) 에서는 $0.613,0.653,0.689,0.718,0.753,0.778 \mathrm{~mm}$ 였 다. 국내 시골 지역의 코호트 연구(ARIRANG study)에서 건 강한 사람 433 명에서 측정한 평균 총경동맥 내중막두께는 연 령 40-49, 50-59, 60-70세에 따라 남성에서는 $0.55,0.59$,
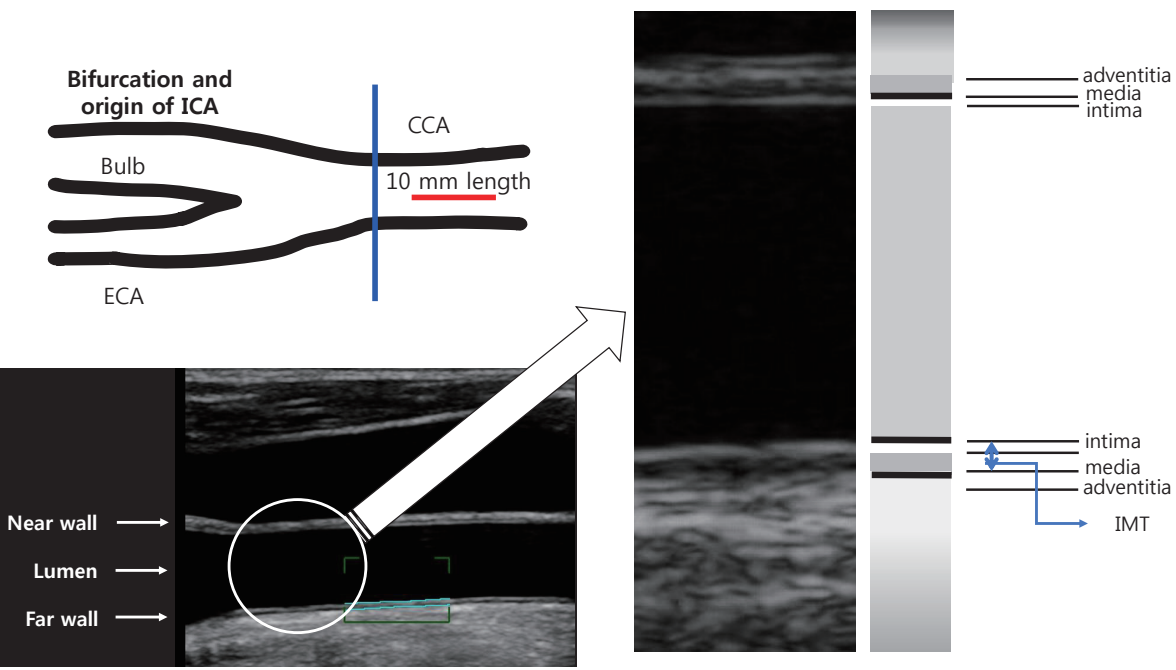

FIG. 17. Representative image of carotid artery and IMT measurement (B mode). ${ }^{18}$ IMT; intima-media thickness, CCA; common carotid artery, ICA; internal carotid artery, ECA; external carotid artery.

TABLE 1. Description of plaque characteristics in ultrasound examination

\begin{tabular}{|c|c|}
\hline Characteristic & Description \\
\hline Number & Single, multiple \\
\hline Location & Affected vessel, near or far wall, lateral or medial wall \\
\hline Form & Concentric, eccentric, marginal \\
\hline Size & Thickness, length \\
\hline Surface & Smooth, irregular, ulcerated \\
\hline Echogenicity & Anechoic, hypoechoic, echogenic, hyperechoic, calcified/acoustic shadowing \\
\hline Texture & Homogenous, heterogeneous/mixed, intraplaque hemorrhage \\
\hline Motion & Radial, longitudinal \\
\hline
\end{tabular}


$0.66 \mathrm{~mm}$ 였고 여성에서는 $0.48,0.55,0.63 \mathrm{~mm}$ 였다. ${ }^{20}$ 내중 막두께는 75 백분위수 이상인 경우 증가되었다고 보며 심혈관 질환 위험이 증가되는 것으로 여겨진다. ${ }^{10}$ 하지만 이를 바탕으 로 적극적인 예방치료를 해야 하는지는 아직 명확하지 않다.

최근 2,204명을 대상으로 한 연구에 따르면 우리나라 남성 (1,147명)의 내중막 두께는 오른쪽 경동맥이 $0.696 \mathrm{~mm}$, 왼쪽 경동맥이 $0.708 \mathrm{~mm}$ 였으며 여성(1,057명)에서는 각각 0.686 $\mathrm{mm}, 0.686 \mathrm{~mm}$ 였고 나이에 따라 점차 두꺼워지는 양상을 보 였다. ${ }^{21}$ 이 연구에서는 직접적으로 비교하지 않았지만 보고에 따른 서양인 및 같은 동양권인 중국인과 비교하여 얇은 결과를 보였다.

\section{죽상판}

Mannheim consensus에 의하면 죽상판은 주위 내중막두께 기준 $0.5 \mathrm{~mm}$ 또는 $50 \%$ 이상 동맥내강에 국소적으로 돌출된 경우 또는 내중막두께가 $1.5 \mathrm{~mm}$ 를 넘는 경우로 정의하였다. ${ }^{18}$ 죽상판은 일반적으로 혈관 한쪽으로 치우친 모양이므로 다양 한 각도에서 검사를 시행하여야 정확한 측정이 가능하다. 종단 면 및 횡단면의 영상을 통하여 죽상판의 두께, 면적, 위치, 개 수, 모양, 에코음영을 기술한다(Table 1).

죽상판의 궤양(ulceration), 신생혈관(neovascularity), 무 에코음영(echolucency), 죽상판내 또는 표면에 움직이는 부분 이 있는 경우 증상과 관련될 가능성이 높으며, 이질적인(heterogeneous) 에코음영과 매끈하지 않은 표면을 포함하여 이 러한 소견들이 하나 이상 복합적으로 나타나는 경우 뇌졸중 또 는 일과성 허혈발작과 연관된 죽상판일 가능성이 높다. ${ }^{22}$

\section{검사 결과 보고}

환자 정보, 검사 목적, 측정방법, 양측 각각의 평균 총경동 맥 내중막두께, 죽상판에 대하여 기술한다. 내중막두께 검사 는 주로 무증상 환자에서 심혈관질환 위험도를 평가하기 위해 이용되고 죽상판 유무를 확인하여 죽상경화질환 및 뇌혈관질 환 위험도를 평가하는데 유용하다. 검사 도중 경동맥 종양, 갑 상샘결절, 림프절병 등과 같은 이상 소견을 발견할 수 있는데, 경동맥 초음파가 이를 위한 검사는 아니지만 적절한 진단과 치 료를 받을 수 있도록 이상 소견을 기술하도록 한다.

\section{회색조중앙값(GRAY SCALE MEDIAN, GSM)}

회색조중앙값은 경동맥 죽상판의 에코음영의 정도(저에코일 수록 불안정)를 평가하는데 있어 객관성을 확보하기 위한 방법
으로 고안되었다. 이를 시행하기 위한 프로토콜을 소개하면 다 음과 같다. ${ }^{23}$

1) 역동범위(dynamic range)를 $60 \mathrm{~dB}$ 정도로 맞추고 7 $\mathrm{MHz}$ 이상의 고해상도 선형 탐색자를 이용하여 조사하고 자 하는 죽상판의 최대 정보가 얻어질 수 있는 화면을 얻 는다.

2) 증폭환경(gain setting)을 적절하게 조절하여 혈관 내 혈 액에 잡음(noise)이 없도록, 먼 벽의 내막-중막 및 중 막-외막 경계면이 구분되며, 죽상판 주위의 외막이 고에 코로 보이도록 한다.

3) 시간이득보상곡선(time or depth gain compensation curve)을 수직보다는 약간 비스듬히 조절하여 혈관 가까 운 벽과 먼 벽이 거의 비슷한 정도의 에코강도를 가지도 록 한다.

4) 저에코 죽상판의 경계를 확인하기 위하여 색혈류지도화 를 이용한다.

5) 얻어진 죽상판 영상을 별도의 컴퓨터 내 소프트웨어프로 그램으로 옮긴다(Adobe Photoshop ${ }^{\text {TM }}$ Ver. 3.0 또는 상 위 version이 많이 쓰인다). 회색조 상태에서 분석하기 위해 색정보를 지운다. 컴퓨터 마우스를 이용하여 죽상 판의 외연을 그려 분석 영역을 정한다(혈액의 GSM 계측 값은 0-5, 혈관외막의 계측값은 185-195에 해당; 0은 '에코없음'으로 검정색, 255 는 '가장 높은 에코'로 하얀색 을 가리킨다). 분석된 히스토그램 $\mathrm{x}$ 축에 회색조가, $\mathrm{y}$ 축에 는 각 회색조에 해당하는 픽셀의 수가 나타난다. 이와 함 께 산출되는 GSM을 전체 죽상판의 에코발생도(echogenicity)의 계측값으로 정한다.

\section{혈류량 측정(BLOOD FLOW MEASUREMENT)}

초음파를 이용한 비침습적 뇌혈류량 측정법이 제안된 이 후, ${ }^{24}$ 정상 기준치가 여러 그룹별로 보고된 바 있다. ${ }^{25,26}$

초음파를 이용한 뇌혈류량 측정법은 다음과 같다.

먼저 환자를 편안하게 바로 누운 자세로 10 분 정도 휴식을 취하게 한다. 초음파검사는 $7 \mathrm{MHz}$ (혹은 그 이상) 선형탐색자 를 이용하며, 양측의 내경동맥과 척추동맥에서 검사를 시행한 다. 뇌혈류량을 얻기 위해서는 혈류속도와 혈관내경을 최대한 정확하게 측정한다.

혈류속도와 혈관내경을 얻기 위해서는 두 가지 방법이 사용 된다: 1) 스펙트럼 도플러(spectral Doppler)를 이용한 정량

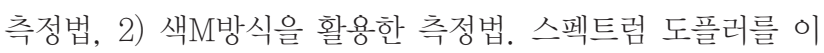
용한 방법은 각도 교정 시평균 평균혈류속도(angle-corrected time-averaged mean flow velocity)와 회색조 영상에 나타나는 혈관 내경을 직접 재는 방법이다. 색 $\mathrm{M}$ 방식을 활용 한 방법은 색속도영상정량화(color velocity imaging quan- 
tification)라고도 하는데 $\mathrm{M}$ 방식에 나타나는 최고수축기속도 혹은 혈관내경이 가장 클 때를 기준으로 한 정지화면으로부터 혈류속도와 혈관 내경값을 동시에 얻는다. 색 $\mathrm{M}$ 방식법을 수행 할 때는 둘러겹침이나 색출혈(color bleed)과 같은 허상이 나 타나지 않도록 유의한다. 선행 연구에서는 스펙트럼 도플러방 법이 색M방식을 이용한 방법보다 혈류량이 의미 있게 높은 것 으로 측정되었는데, 이는 스펙트럼 도플러법에서는 내경이 더 크게 계측되기 때문인 것으로 보고된 바 있다. ${ }^{27}$ 초음파 입사 각이나 표본용적 및 검사 지점 등은 두 검사 모두 동일하며 아 래와 같다.

(1) 초음파 입사각: 가급적 작게 유지하고 대개 $60^{\circ}$ 로 고정 유지한다.

(2) 표본용적: 혈관 내경을 모두 포함하도록 충분히 넓게 유 지한다.

(3) 검사 지점

a. 척추동맥: 대개 $\mathrm{C} 4-5$ 가로돌기 사이에서 측정한다 (검사자에 따라서는 $\mathrm{C} 1-2$ 에서 시행하기도 함).

b. 내경동맥: 가급적 곧게 뻗은 혈관영역에서 측정하는 것을 원칙으로 하며, 내경동맥 분기점 기준, 적어도 2 $\mathrm{cm}$ 상방에서 계측한다.

아래 각 혈관에서의 검사법은 스펙트럼 도플러를 이용한 정

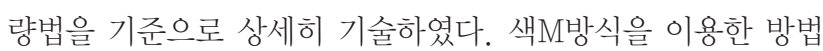
도 충분히 객관적인 수치를 제공하나, 경동맥에 비하여 척추동 맥에서는 창(window) 확보가 용이하지 않은 편이다.

척추동맥에서 검사를 시행할 때는 머리를 검사하고자 하는 방향의 반대측으로 약 $10^{\circ}$ 정도 돌린 채로, 대개 C4-5 가로 돌기 사이에서 측정한다. 혈류속도를 얻기 위해서는 혈관 내 경을 다 포함하도록 넓게 표본용적을 유지시키고 시평균속 도(time-averaged velocity, TAV), 혹은 시평균최대속도 (time-averaged maximum velocity, TAMX)를 적어도 3개 의 심박동에 걸쳐 얻는다. 이후 혈류속도를 얻은 바로 그 지점 에서 내경의 최대값을 얻는다. TAV는 기준선 위, 아래 모든 주파수의 평균을 의미하며, TAMX는 최대혈류속도의 평균값 을 의미한다.

내경동맥의 경우는 검사를 시행할 때 머리를 좀 더 반대측으 로, 약 $25-45^{\circ}$ 정도 돌린 상태에서 내경동맥 분기점보다 적어 도 1.5-2 cm 상방, 혈관이 곧게 뻗은 지점을 선택하여, 위의 척추동맥에서 얻은 방법과 동일하게 혈류속도와 혈관내경을 계측한다.

총경동맥과 외경동맥에서 혈류량을 추가로 동일한 방법으로 얻을 수 있으며, 이를 통하여 내경동맥과 외경동맥 혈류량의 합과 총경동맥 혈류량이 유사한 소견을 얻어 검사의 신뢰도를 높일 수 있다.

상기의 방법으로 혈류속도와 내경을 얻은 후 다음의 공식에 적용하여 각 혈관의 혈류량을 얻고 이후 이를 합산하여 부분별 혹은 총뇌혈류량을 산출한다.
각 혈관에서의 혈류량(flow volume, $\mathrm{Q}, \mathrm{cm}^{3} / \mathrm{sec}$ ) $\mathrm{Q}=\mathrm{TAV} X$ Area 혹은 $\mathrm{Q}=\mathrm{TAMX} / 2 \mathrm{X}$ Area 각혈관의 단면적 $(\mathrm{area})=\pi(\mathrm{d} / 2)^{2}$ 전뇌혈류량 $\left(\mathrm{CBF}, \mathrm{cm}^{3} / \mathrm{sec}\right)=\mathrm{Q}_{\text {left ICA }}+\mathrm{Q}_{\text {right ICA }}$ 후뇌혈류량 $\left(\mathrm{CBF}, \mathrm{cm}^{3} / \mathrm{sec}\right)=Q_{\text {left VA }}+Q_{\text {right VA }}$ 총뇌혈류량 $\left(\mathrm{CBF}, \mathrm{cm}^{3} / \mathrm{sec}\right)=Q_{\text {left ICA }}+Q_{\text {right ICA }}$

$$
+Q_{\text {left VA }}+Q_{\text {right VA }}
$$

단, $\mathrm{CBF}$; cerebral blood flow, d; diameter, ICA; internal carotid artery, TAMX; time-averaged maximum velocity, TAV; time-averaged velocity, VA; vertebral artery.

\section{경정맥의 해부학과 초음파검사법(ANATOMY OF JUGULAR VEINS AND ULTRASOUND EX- AMINATION)}

대뇌정맥배출은 목의 두개외 정맥계로 대부분 이루어지 며 내경정맥(internal jugular vein), 척추정맥계(vertebral venous system), 심부목정맥(deep cervical vein)이 주된 경 로이다. 이들 대뇌정맥유출로는 목에서 다양한 문합(anastomosis)을 이루는데 머리와 목 경계에서 두드러진다. 내경정맥 과 척추정맥은 초음파로 쉽게 확인하고 역동적으로 검사할 수 있다. ${ }^{28}$

\section{1. 경정맥}

내경정맥은 목에서 가장 큰 정맥이며 대뇌정맥유출의 주된 경로로 특히 바로 누운 자세에서 그 역할을 수행한다. 대뇌정 맥흐름은 대부분 표재와 심부정맥계에서 가로정맥굴(transverse sinus)로 진행되며 구불정맥굴(sigmoid sinus)로 이어 져 내경정맥으로 배출된다. 내경정맥은 빗장밑정맥(subclavian vein)으로 합류되어 팔머리정맥(brachiocephalic vein) 을 구성하고 양쪽의 팔머리정맥이 위대정맥(superior vena cava)으로 이어져 대뇌정맥혈을 우심방으로 배출한다.

내경정맥은 경정맥구멍(jugular foramen)에서 아래바위 정맥굴(inferior petrosal sinus)과 구불정맥굴의 연결부위로 부터 시작된다. 이 부위는 약간 팽대되어 있어서 경정맥팽대 (jugular bulb)라고 하며 초음파로는 보이지 않는다. 고리뼈 (atlas)의 가로돌기 앞을 지나가기 때문에 두 구조물 사이에 병터가 생길 경우 경정맥압박이 발생하기도 한다. 그 아래 둘 째 목빼에서 경동맥과 내경정맥을 쉽게 확인할 수 있다.

내경정맥은 내경동맥의 약간 전외측으로 진행하는 경로가 가장 흔한데, $69.5 \%$ 에서는 $1 \mathrm{~mm}$ 의 거리를 두고 있는 것으로 보고되었다. ${ }^{29}$ 내경정맥과 총경동맥 경로의 해부학적 변이는 빈번한 편인데, 내경정맥은 목빗근(sternocleidomastoid) 앞 가장자리의 바닥으로 주행하여 빗장밑정맥과 합류하여 팔머리 
정맥이 된다.

CT혈관조영술로 내경정맥과 경동맥의 해부학적 관계를 조 사한 연구에서 총 176 개의 좌우 경정맥을 총경동맥과 비교하 였을 때, $85.2 \%$ 에서는 옆쪽, $12.5 \%$ 에서는 앞쪽, $1.1 \%$ 에서는 안쪽, $1.1 \%$ 에서 바깥쪽에 위치하고 있었다. ${ }^{29}$ 게다가 내경정 맥관삽입 위치 선정을 위하여 내경정맥과 총경동맥의 겹침의 정도를 1,000 개 이상의 정맥을 대상으로 한 초음파 연구에서, $54 \%$ 에서 내경정맥이 총경동맥과 겹치고 있어서, 시술시 경동 맥파열 위험성이 있었다. ${ }^{30}$ 특히 고개 위치에 따라, 중립위치 에서 우측으로 하거나 $(23.3 \rightarrow 39.2 \%)$ 좌측으로 하면 $(35.3 \rightarrow$ $52.8 \%$ ) 내경정맥과 총경동맥이 더 많이 겹쳐졌고, 고개를 돌 리면 내경정맥이 총경동맥 옆에 놓일 확률이 감소하였다(우측 $40 \rightarrow 21 \%$, 좌측 $26.5 \rightarrow 10.5 \%$ ). ${ }^{31}$ 즉 우측 경정맥이 좌측에 비해서 총경동맥 옆에 놓이며, 총경동맥과 겹쳐질 확률이 작아 도관삽입할 때 선호된다.

내경정맥의 판막기관은 내경정맥이 구불정맥굴과 합류하는 지점 근처에 위치하며 부검연구에서 86-93\%의 정맥에 존재 한다고 알려졌다. ${ }^{32}$

초음파로 내경정맥을 검사할 때, 다음의 세 분절을 구분해서 본다(Fig. 18).

- 원위부 J3: 경동맥분기 하부로 둘러싸여 있고 총안면정맥 (common facial vein)이 합류하는 지점

- 중간부 $\mathrm{J} 2$ : 경동맥분기와 판막위(supravavular)면 사이

- 근위부 $\mathrm{J} 1$ : 판막면과 판막위 팽대 사이

내경정맥의 해부학적 구조이상은 드문데, 예를 들어 내경정 맥의 중복은 편측경부박리의 $0.4 \%$ 수준이다. ${ }^{33}$

\section{2. 내경정맥의 판막}

내경정맥판막은 편측 혹은 양측 정맥에서 $72-96 \%$ 의 빈도 로 관찰된다. ${ }^{34,35}$ 남녀비 연구는 아직 보고되지 않았으며, 편 측인 경우 우측이 더 흔하였다. Murase 등 ${ }^{36}$ 은 우측 경정맥판 막의 $88 \%$ 가 기능적인 반면 좌측 경정맥판막은 $44 \%$ 에서만 기 능적이어서, 대뇌정맥배출은 비대칭적으로 우측이 더 우세하

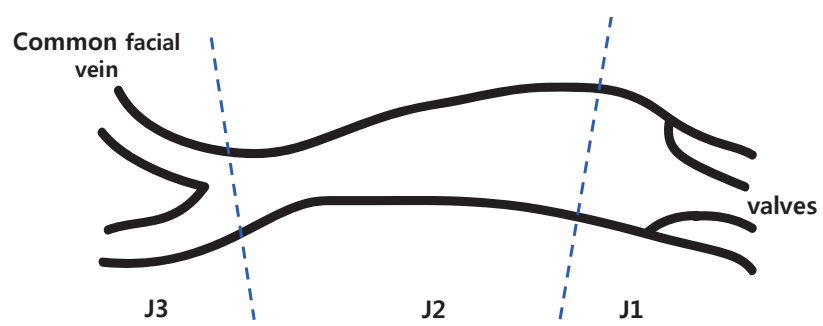

FIG. 18. Schematic drawing of IJV and its segments. J1 or proximal segment, focused to the valve system. J2 or intermediate segment. $\mathrm{J} 3$ or distal segment, where the common facial vein ends into the IJV. IJV; internal jugular vein.
다고 보고하였다. 따라서 우성부위 판막이 더 흔한 것으로 추 정된다.

판막첨판(valve cusp)은 육안적으로 반투명하며 대부분의 경우(66-90\%) 두 개의 첨판으로 구성된다. 일첨판은 두 번째 로 흔하며 삼천판은 6-7\% 정도였다. ${ }^{35}$

판막은 내경정맥의 $\mathrm{J} 1$ 즉 경정맥팽대의 근위부에 위치한다. 생리학적으로 판막은 확장기 동안 완전히 닫혀서 우심방의 압 력이 위대정맥과 팔머리정맥을 통하여 내경정맥으로 역행전달 되는 것을 차단한다. ${ }^{34}$

\section{3. 내경정맥의 크기와 단면적}

내경정맥의 단면적(cross-sectional area, CSA)과 대칭성 의 정상범위는 넓다. 고찰 가능한 문헌들은 대부분 정상인이 아닌 경정맥 도관삽입을 위한 중환자들을 대상으로 하였기 때 문에 정상치 추정은 쉽지 않다. CT혈관조영술 연구는 내경정

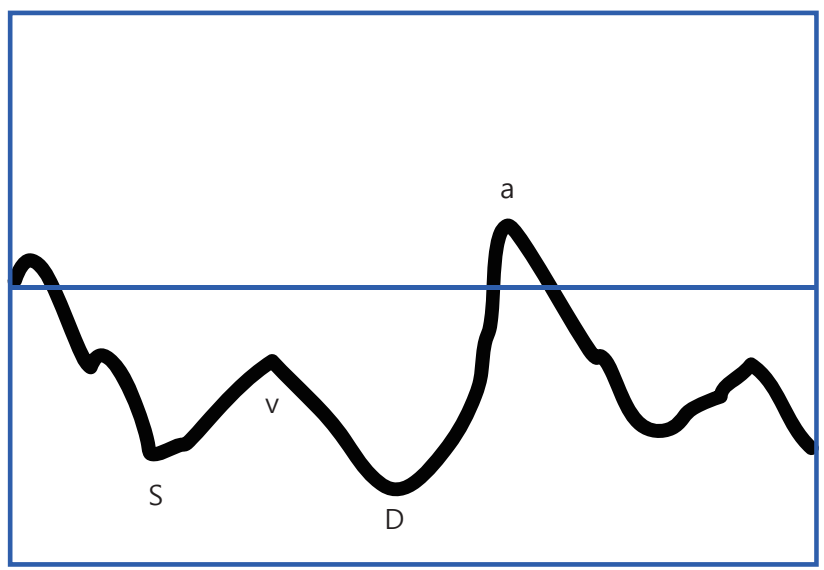

FIG. 19. Schematic drawing of the venous flow pattern in the central veins.

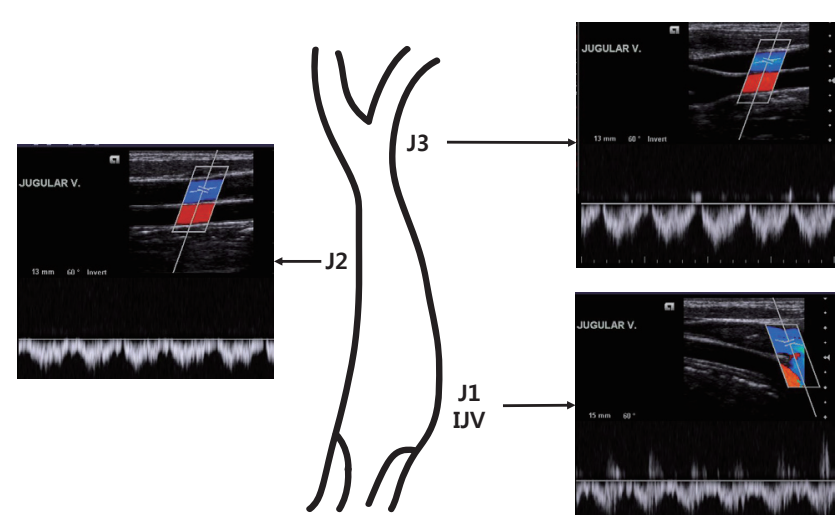

FIG. 20. Longitudinal scan of IJV at the level of $\mathrm{J} 1, \mathrm{~J} 2$, J 3 in color mode and Doppler mode; the variation of the Doppler waveforms. IJV; internal jugular vein. 
Lee SJ and Yu S, et al. Standard Examination of Extracranial Neck Vessels

맥 단면적에 대한 호흡동력학의 영향을 평가할 수 없지만 몇 몇 연구들을 보면 J2 수준에서 내경정맥의 직경이 9.1-10.2 $\mathrm{mm}$, 작은 경정맥에서는 $5 \mathrm{~mm}$ 였다. ${ }^{37}$ 양측 내경정맥 직경 을 평가한 CT혈관조영술 연구에서는 $80.5 \%$ 에서 우측 내경정 맥이 우세하였고 $3.9 \%$ 에서는 형성저하(hypoplasia)가 있었 다. ${ }^{29}$ 따라서 중심정맥도관 삽입을 위해서는 우측 내경정맥을 선호할 수 있다.

내경정맥의 직경과 판막의 유무에서 성별과 연령이 주는 차 이는 없다. ${ }^{38}$

내경정맥의 크기에 영향을 주는 인자들은 다음과 같다: 수액 공급상태, 흥강내압을 결정하는 심폐기능상태, 머리 위치, 경 정맥에 압력을 가할 수 있는 경부 구조물. 고개를 반대쪽으로 돌리는 자세 수기도 반대쪽 경정맥압을 감소시키면서 경정맥 영역을 증가시킨다. Trendelenburg 자세에서도 내경정맥영 역이 커진다.

경정맥판막 아래의 팽대가 국소적으로 확장되는 경정맥확장 증(phlebectasia)도 내경정맥영역에 영향을 미치며 보통 양성 경과를 보인다. 소아에서 많고 하부 경부의 덩이(mass)로 관 찰되며 흥강내압의 영향을 직접 받는 우측에서 흔하다. 초음파 로 보면 방추형으로 확장된 혈관이 관찰되며 발살바수기 후 정 상 또는 반대측과 크기를 비교하여 차이를 확인한다. 정상에서 는 발살바수기 후 경정맥직경이 22 배 증가하고 경정맥확장증 에서는 72 배 커진다. ${ }^{39}$

\section{4. 도플러파형}

심장수축과 흥강내압의 변화는 도플러파형에 반영된다. 호 기나 발살바수기시 흥강내압이 증가하면 정맥환류가 감소하여 내경정맥의 직경이 증가하며 정맥혈류는 거의 없다. 흡기시에 는 흥강내압이 음압이 되어 정맥혈류가 증가하여 큰 진폭의 도 플러파형이 생긴다.

전형적인 도플러파형은 빗장밑동맥 수준에서 $\mathrm{S}, \mathrm{v}, \mathrm{D}, \mathrm{a}$ 파 로 보이는데 J1분절에서도 관찰된다. 정상정맥혈류는 심장운 동과 호흡 관련 주기 변화에 의하여 결정되는 역행박동성의 영 향을 받는다. 정맥파형에서의 호흡주기는 흥강과 정맥 사이의 거리와 같은 인자들의 영향을 받는다(Figs. 19 and 20).

- S: 심장 끝으로의 방실중격의 운동과 심방내음압으로 결 정되는 수축기파형

- v: 충만기 동안의 우심방의 과잉확장으로 생성되는 심방 내양압의 결과

- D: 심방내음압으로 결정되는 확장기파형으로 삼첨판개방 의 결과

- a: 심방내압을 반영

\section{REFERENCES}

1. Sakalauskas A, Špečkauskienè V, Laučkaite K, Jurkonis R, Rastenyte D, Lukoševičius A. Transcranial ultrasonographic image analysis system for decision support in parkinson disease. J Ultrasound Med. 2018;37:1753-1761.

2. Kim JS, Seok HY, Kim BJ. The significance of muscle echo intensity on ultrasound for focal neuropathy: the medianto ulnar-innervated muscle echo intensity ratio in carpal tunnel syndrome. Clin Neurophysiol. 2016;127:880-885.

3. McCormick TJ, Miller EC, Chen R, Naik VN. Acquiring and maintaining point-of-care ultrasound (POCUS) competence for anesthesiologists. Can J Anesth. 2018;65:427-436.

4. Zieleskiewicz L, Muller L, Lakhal K, Meresse Z, Arbelot C, Bertrand PM, et al. Point-of-care ultrasound in intensive care units: assessment of 1073 procedures in a multicentric, prospective, observational study. Intensive Care Med. 2015;41:1638-1647.

5. Lee JY, Yu S, Lee SI, Jung KH, Seo WK, Park JM, et al. Transcranial Doppler ultrasound: practice standards part I. Test performance and interpretation. J Neursonology. 2016;8:1-13.

6. Jung KH, Seo WK, Park JM, Lee JY, Yu S, Lee SI, et al. Transcranial Doppler ultrasound: practice standards part II. Clinical indications and utility. J Neursonology. 2016;8:14-29.

7. Cure J. Anatomy of the brain's arterial supply. In: Alexandrov AV. Cerebrovascular ultrasound in stroke prevention and treatment. 2nd ed. Oxford: Wiley-Blackwell, 2011;26-44.

8. Bartels E. Vertebral sonography. In: Tegeler $\mathrm{CH}$, Babikian VL, Gomez CR. Neurosonology. St. Louis: Mosby-Year Book, 1996;83-100.

9. Riley WA. Physics and principles of ultrasound and instrumentation. In: Tegeler CH, Babikian VL, Gomez CR. Neurosonology. St. Louis: Mosby-Year Book, 1996;3-7.

10. Stein JH, Korcarz CE, Hurst RT, Lonn E, Kendall CB, Mohler ER, et al. Use of carotid ultrasound to identify subclinical vascular disease and evaluate cardiovascular disease risk: a consensus statement from the American Society of Echocardiography Carotid Intima-Media Thickness Task Force. Endorsed by the Society for Vascular Medicine. J Am Soc Echocardiogr. 2008;21:93-111.

11. Eicke BM, Tegeler CH. Doppler ultrasonography: physics and principles. In: Tegeler CH, Babikian VL, Gomez CR. Neurosonology. St. Louis: Mosby-Year Book, 1996;8-13.

12. Knappertz VA, Tegeler CH. Color flow imaging. In: Tegeler CH, Babikian VL, Gomez CR. Neurosonology. St. Louis: Mosby-Year Book, 1996;19-33. 
13. Alexandrov AV, Robinson-Vaughn A, Balucani C, Neumyer MM. Principles of extracranial ultrasound examination. In: Alexandrov AV. Cerebrovascular ultrasound in stroke prevention and treatment. 2nd ed. Oxford: Wiley-Blackwell, 2011;3-12.

14. Lee W. General principles of carotid Doppler ultrasonography. Ultrasonography. 2014;33:11-17.

15. Jeng JS, Yip PK. Evaluation of vertebral artery hypoplasia and asymmetry by color-coded duplex ultrasonography. Ultrasound Med Biol. 2004;30:605-609.

16. Park JH, Kim JM, Roh JK. Hypoplastic vertebral artery: frequency and associations with ischaemic stroke territory. J Neurol Neurosurg Psychiatry. 2007;78:954-958.

17. Mantero A, Gentile F, Azzollini M, Barbier P, Beretta L, Casazza F, et al. Effect of sample volume location on Doppler-derived transmitral inflow velocity values in 288 normal subjects 20 to 80 years old: an echocardiographic, two-dimensional color Doppler cooperative study. J Am Soc Echocardiogr. 1998;11:280-288.

18. Touboul PJ, Hennerici MG, Meairs S, Adams H, Amarenco P, Bornstein N, et al. Mannheim carotid intima-media thickness and plaque consensus (2004-2006-2011). An update on behalf of the advisory board of the 3rd, 4 th and 5th watching the risk symposia, at the 13th, $15^{\text {th }}$ and 20 th european stroke conferences, mannheim, germany, 2004, brussels, belgium, 2006, and hamburg, germany, 2011. Cerebrovascular diseases. 2012;34:290-296.

19. Lee YH, Shin MH, Kweon SS, Nam HS, Park KS, Choi JS, et al. Normative and mean carotid intima-media thickness values according to metabolic syndrome in Koreans: the Namwon study. Atherosclerosis. 2014;234:230-236.

20. Youn YJ, Lee NS, Kim JY, Lee JW, Sung JK, Ahn SG, et al. Normative values and correlates of mean common carotid intima-media thickness in the Korean rural middle-aged population: the atherosclerosis risk of rural areas in Korea general population (Arirang) study. J Korean Med Sci. 2011;26:365-371.

21. Bae JH, Kim WS, Lee MS, Kim KS, Park JB, Youn HJ, et al. The changes of individual carotid artery wall layer by aging and carotid intima-media thickness value for high risk. Cardiovasc Ther. 2016;34:397-403.

22. Brinjikji W, Rabinstein AA, Lanzino G, Murad MH, Williamson EE, DeMarco JK, et al. Ultrasound characteristics of symptomatic carotid plaques: a systematic review and meta-analysis. Cerebrovasc Dis. 2015;40:165-174.

23. Elatrozy T, Nicolaides A, Tegos T, Zarka AZ, Griffin M, Sabe- tai M. The effect of B-mode ultrasonic image standardisation on the echodensity of symptomatic and asymptomatic carotid bifurcation plaques. Int Angiol. 1998;17:179-186.

24. Furuhata H, Suzuki N, Yoshimura S, Kodaira K, Aoyagi T, Obara K, et al. Non-invasive and quantitative measurement of volume flow-rate at internal and external carotid and vertebral arteries. Ultrasound Med Biol. 1983;Suppl 2:239-242.

25. Schöning M, Walter J, Scheel P. Estimation of cerebral blood flow through color duplex sonography of the carotid and vertebral arteries in healthy adults. Stroke. 1994;25:17-22.

26. Scheel P, Ruge C, Petruch UR, Schoning M. Color duplex measurement of cerebral blood flow volume in healthy adults. Stroke. 2000;31:147-150.

27. Ho SS, Chan YL, Yeung DK, Metreweli C. Blood flow volume quantification of cerebral ischemia: comparison of three noninvasive imaging techniques of carotid and vertebral arteries. AJR Am J Roentgenol. 2002;178:551-556.

28. Malferrari G, Zedde M. Prati P. Neurosonological evaluation of cerebral venous outflow: an Ultrasound Atlas. 1st ed. Berlin: Springer, 2014;9-13.

29. Lim CL, Keshava SN, Lea M. Anatomical variations of the internal jugular veins and their relationship to the carotid arteries: a CT evaluation. Australas Radiol. 2006;50:314-318.

30. Troianos CA, Kuwik RJ, Pasqual JR, Lim AJ, Odasso DP. Internal jugular vein and carotid artery anatomic relation as determined by ultrasonography. Anesthesiology. 1996;85:4348.

31. Hong JY, Koo BN, Kim WO, Choi E, Kil HK. Effect of head rotation on overlap and relative position of internal jugular vein to carotid artery in infants and children: a study of the anatomy using ultrasonography. J Crit Care. 2010;25:360.e9360.e13.

32. Dresser LP, McKinney WM. Anatomic and pathophysiologic studies of the human internal jugular valve. Am J Surg. 1987;154:220-224.

33. Prades JM, Timoshenko A, Dumollard JM, Durand M, Merzougui N, Martin C. High duplication of the internal jugular veins: clinical incidence in the adult and surgical consequences, a report of three clinical cases. Surg Radiol Anat. 2002;24:129-132.

34. Lepori D, Capasso P, Fournier D, Genton CY, Schnyder P. High-resolution ultrasound evaluation of internal jugular venous valves. Eur Radiol. 1999;9:1222-1226.

35. Darge K, Brandis U, Zieger B, Rohrschneider W, Wunsch $\mathrm{R}$, Troeger J. Internal jugular venous valves in children: high-resolution US findings. Eur Radiol. 2001;11:655-658. 
36. Murase M, Maeda M, Teranisi K, Sakurai H, Nisizawa T, Murayama H. Morphological and functional study of internal jugular vein valve. Jpn J Cardiovasc Surg. 1993;22:383-386.

37. Lin BS, Kong CW, Tarng DC, Huang TP, Tang GJ. Anatomical variation of the internal jugular vein and its impact on temporary haemodialysis vascular access: an ultrasonographic survey in uremic patients. Nephrol Dial Transplant. 1998;13:134-138.
38. Mortensen JD, Talbot S, Burkart JA. Cross-sectional internal diameters of human cervical and femoral blood vessels: relationship to subject's sex, age, and body size. Anat Rec. 1990;225:115-124.

39. Chao HC, Wong KS, Lin SJ, Kong MS, Lin TY. Ultrasonographic diagnosis and color flow Doppler sonography of internal jugular venous ectasia in children. J Ultrasound Med. 1999;18:411-416. 